\title{
Гетероструктура карбид кремния на кремнии для солнечных элементов
}

\author{
В.В. Танеев, А.В. Щербак \\ Самарский национальный исследовательский университет им. академика С.П. Королева, \\ 2. Самара, 443086, Московское шоссе, 34 \\ тел:+7 (937) 186-9644, эл. почта: vadim@taneev.ru
}

DOI 10.34077/RCSP2019-115

Увеличение производства энергии до сих пор происходило в основном за счет использования ископаемых источников энергии - нефти, природного газа, угля, ядерного топлива. Однако удовлетворить дальнейший рост энергопотребления только за счет использования ископаемых источников невозможно [1].

Одним из самых привлекательных и перспективных возобновляемых источников энергии на сегодняшний день является фотовольтаика, т. е. прямое преобразование солнечной энергии в электрическую [2-5].

Для того чтобы солнечная энергия могла соперничать с ископаемыми источниками энергии, необходимо снизить цену на энергию, вырабатываемую солнечными элементами в несколько раз. Соответственно нужно создать дешевую и эффективную технологию и конструкцию фотоэлектрических преобразователей.

В данной работе рассмотрены основные фотоэлектрические процессы в полупроводниковых преобразователях оптического излучения. Подробно рассмотрены механизмы, приводящие к снижению эффективности фотопреобразователей солнечного излучения. Для увеличения КПД фотопреобразователей предлагается использовать пористые структуры.

Рассмотрены способы получения пористого кремния и пористого карбида кремния.

Исследована морфология поверхности полученных образцов пористого карбида кремния. Процесс карбидизации не нарушает морфологию поверхности исходного пористого кремния.

Получены спектры отражения образцов пористого карбида кремния, пористого кремния, а также текстурированного кремния. Коэффициент отражения пористых слоев существенно ниже коэффициента отражения текстурированной поверхности. Нанесение просветляющего покрытия на пористый кремний повышает коэффициент отражения, в то время как карбидизация пористого кремния методом эндотаксии не увеличивает коэффициент отражения.

Проведено исследование удельного поверхностного сопротивления и времени жизни избыточных носителей заряда в пористом карбиде кремния. Показано, что удельное поверхностное сопротивление снижается практически на порядок, а время жизни существенно увеличивается (в 15 - 20 раз) по сравнению с аналогичными параметрами пористого кремния. Применение структур пористого карбида кремния в фотоэлектрических преобразователях перспективно для увеличения их эффективности.

\section{Лuтература}

[1] Перспективы энергетических технологий 2008. Сценарии и стратегии до 2050 г. Международное энергетическое агентство. OECD/IEA, 2008.

[2] Де Роза А. Возобновляемые источники энергии. Физико-техническиеосновы: Учебн. Пособие [текст]// Пер. с англ. Долгопрудный: Изд. дом «Интеллект»; М.: Изд. дом МЭИ, 2010. 704.

[3] Рязанов К. В. Перспективы развития солнечной энергетики [текст]/КАБЕЛЬ-news. 2009. № 121. C. $81-85$.

[4] Ежов В. Тенденции развития электронных технологий. Ближайшиеперспективы [текст]/ В.

Ежов// Новая электроника России 2009: Отраслевой деловой ежегодник. С. 11-17.

[5] Thin-film silicon solar cells. Editor: Arvind Shah [текст]// EPFL Press, 2010. 430 p. 